\title{
Determinants of share repurchases: A quantile regression approach
}

\author{
Ioannis Chasiotis $^{1, *} \cdot$ Andreas G. Georgantopoulos ${ }^{2} \cdot$ Nikolaos Eriotis $^{2}$ \\ ${ }^{1}$ School of Business and Economics, Athens Metropolitan College, Athens, Greece \\ ${ }^{2}$ National and Kapodistrian University of Athens, Greece
}

Received: 27 February 2020

Revised:11 May 2020

Accepted: 16 June 2020

\begin{abstract}
This study utilizes quantile regressions to investigate the effect of the determinants of share repurchases on firms at different points of the share repurchases distribution. Empirical results from a large panel of NYSE repurchasing firms, document an asymmetric effect of several determinants on share repurchases in terms of size, significance and direction. Excess capital, stock options and growth opportunities are significant throughout the distribution and their impact increases at successive quantiles while ownership concentration and leverage exhibit sign reversals between lower and upper quantiles. These differing effects are attributed to highly heterogeneous firm characteristics across quantiles. ${ }^{1}$
\end{abstract}

Keywords: share repurchases; quantile regressions; NYSE

JEL Classification Codes: G32, G35

\section{Introduction}

Share repurchases in the United States came recently under the spotlight due to their historically elevated levels and association with distorted incentives. Consequently, several economists and policymakers called for much stricter regulation on this distribution mechanism. Therefore, it is of importance to gain a more complete understanding of the determinants behind share repurchases.

Empirical research so far has employed conventional conditional mean estimators which explain the impact of typical determinants on the 'average', in terms of repurchase activity, firm. An important question which remains unanswered in the literature is whether these determinants have a differing impact on share repurchases across firms with different repurchase activity. If this is the case, conditional mean estimators lead to a crucial loss of information. The possibility of such a differing impact is suggested by extant theories and hinted by the

\footnotetext{
*Corresponding author. E-mail: ioannis.chasiotis@dunelm.org.uk.

Citation: Chasiotis I., Georgantopoulos, A. G., and Eriotis, N. (2021) Determinants of share repurchases: A quantile regression approach, Economics and Business Letters, 10(1), 27-36.
}

DOI: $10.17811 /$ ebl.10.1.2021.27-36

${ }^{1}$ The majority of this work was completed when Chasiotis, I. was a doctoral researcher at Durham University Business School. 
presence of conflicting results in previous empirical studies. The free cash flow theory by Jensen (1986) suggests that debt, dividends and share repurchases can be utilized to reduce the agency costs of free cash flows. Moreover, firms may use share repurchases to reduce asymmetric information costs by signaling their stock's undervaluation to the market. Therefore, different levels of repurchase activity suggest different levels of agency and asymmetric information costs (Jensen 1986; Brav et al. 2005). So, factors that may be significant to some firms may be insignificant to others. Changes in size, significance, or even the sign of the respective coefficients in earlier studies support this contention ${ }^{2}$. A representative example concerns leverage and stock undervaluation. According to the theoretical and empirical literature share repurchases are used to signal and/or exploit undervaluation, to adjust capital structure and can substitute for debt in alleviating free cash flow issues. However, relevant empirical evidence is inconclusive as between a number of studies, the impact of the leverage and stock return (proxy for undervaluation) variables ranges from negative, to positive, to statistically insignificant. $^{2}$

Therefore, this study aims to investigate if the effect of the determinants of share repurchases varies between firms in different quantiles of the share repurchases distribution. Accordingly, we employ the quantile regression approach by Koenker and Bassett (1978), as this estimation method can provide information about the impact of the independent variables at points in the dependent variable's distribution other than the conditional mean. This approach has been proven useful in the corporate finance literature as it yielded new insights regarding the determinants of capital structure (see Fatouh et al. 2005, 2008; Sanchez Vidal 2014). However, to the best of our knowledge this is the first study to use a quantile regression approach to analyze the determinants of share repurchases.

\section{Data and methodology}

As we focus on the United States our initial sample comprises of firms listed in the New York Stock Exchange (NYSE). We choose 2000-2018 as our sample period in order to have sufficient yearly observations before and after the financial crisis. Thomson Reuters Datastream is the source of our data. Following common practice, we exclude from our sample financial and utilities firms, firms with missing observations and firms which do not engage in share repurchases. Our final sample consists of a large panel of 4281 firm-year observations.

Following Fatouh et al. (2005), we investigate the degree of heterogeneity in our sample in terms of firm behavior and firm characteristics. Fig. 1 shows the annual share repurchases to total assets ratio3 over 2000-2018 at several quantiles of the distribution.

A first look suggests that US firms exhibit a high level of heterogeneity regarding repurchase behavior over time. Repurchase activity, as portrayed by the mean value of the share repurchases ratio, exhibits a notable increase between 2003-followed by a steep decrease during the financial crisis of 2007-2009.After 2009, the share repurchase ratio increased again reaching pre-crisis levels. However, the evolution of the mean is driven by the repurchase behaviour of firms in the upper quantiles of the distribution. On the contrary, firms in the lower end show only minor to no fluctuations regarding their share repurchase activity. Moreover, the mean is steadily higher than the median showing that the share repurchases ratio distribution is right-skewed. Table 1 presents a number of firm characteristics, at different quantiles of the

\footnotetext{
${ }^{2}$ See Dittmar (2000), Kahle (2002), Bens et al (2003), Oswald and Young (2008), Benhamouda (2010), Lee and Suh (2011).

${ }^{3}$ We follow Lee and Suh (2011) and Almeida et al. (2016), and define the share repurchases ratio as share repurchases to total assets. The advantage over scaling by earnings is that the latter lead us to omit observations with negative values. Also, cases with very low earnings lead to abnormally high, share repurchases and dividend payout ratios.
} 
Figure 1. Share repurchases to total assets over 2000-2018.

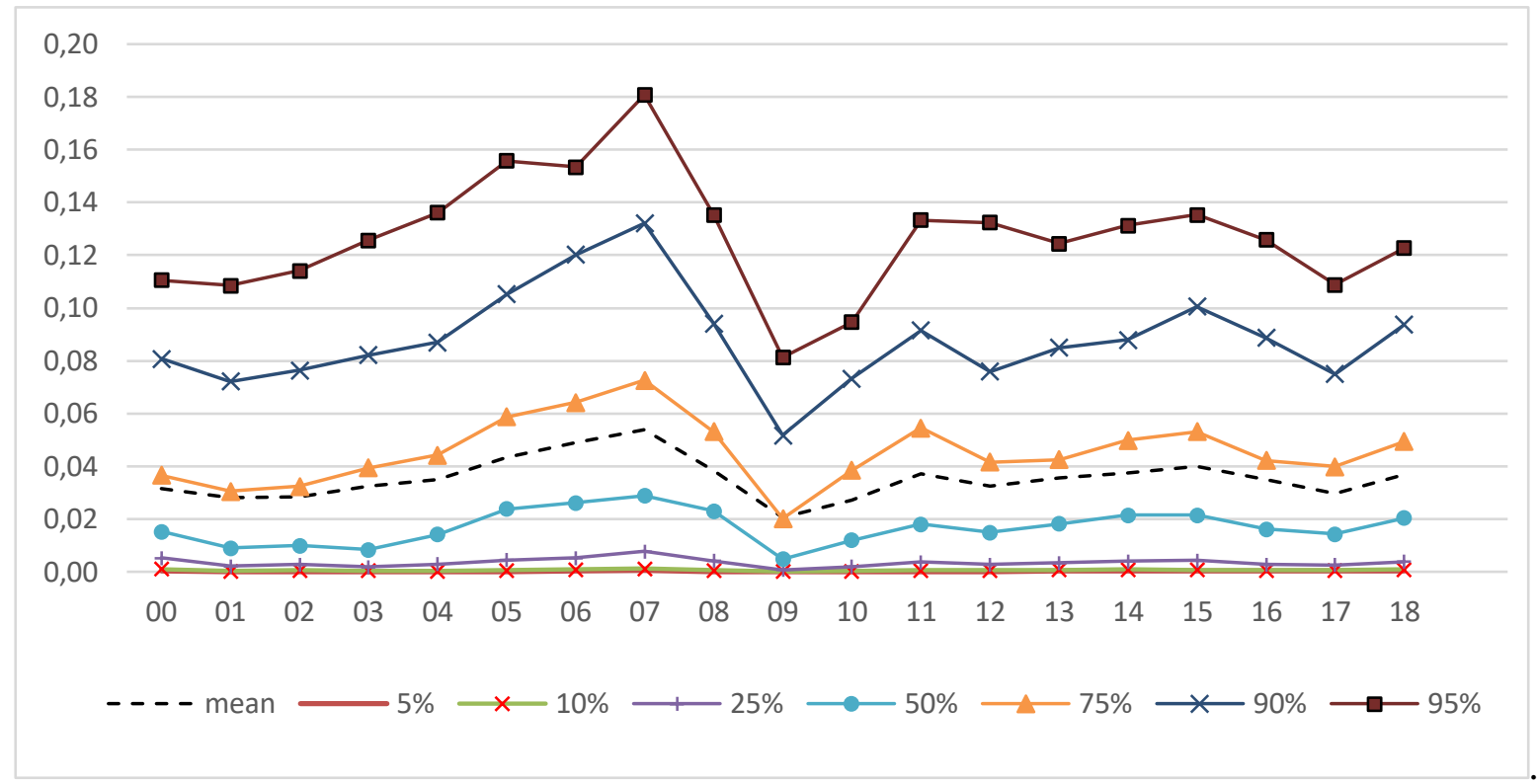

Table 1. Firm characteristics at different quantiles of the share repurchases distribution over 2000-2018.

\begin{tabular}{lrrrrrrrr}
\hline \hline & $<\mathbf{5 \%}$ & $\mathbf{5 \%}$ & $\mathbf{1 0 \%}$ & $\mathbf{2 5 \%}$ & $\mathbf{5 0 \%}$ & $\mathbf{7 5 \%}$ & $\mathbf{9 0 \%}$ & $\mathbf{9 5 \%}$ \\
\hline \hline FCF & 0,07 & 0,09 & 0,09 & 0,10 & 0,12 & 0,14 & 0,17 & 0,20 \\
CASH & 0,07 & 0,06 & 0,08 & 0,09 & 0,11 & 0,13 & 0,15 & 0,20 \\
OPTIONS & 0,001 & 0,002 & 0,002 & 0,003 & 0,005 & 0,007 & 0,009 & 0,012 \\
DIV & 0,01 & 0,01 & 0,01 & 0,02 & 0,02 & 0,03 & 0,03 & 0,03 \\
GROWTH & 0,05 & 0,06 & 0,05 & 0,04 & 0,04 & 0,04 & 0,05 & 0,04 \\
LEV & 0,23 & 0,24 & 0,22 & 0,20 & 0,21 & 0,19 & 0,17 & 0,16 \\
OWNCON & 0,13 & 0,12 & 0,15 & 0,14 & 0,10 & 0,10 & 0,12 & 0,18 \\
\hline No. obs & 214 & 214 & 643 & 1070 & 1070 & 641 & 215 & 214 \\
\hline \hline
\end{tabular}

share repurchases ratio distribution. There are notable differences between firm characteristics in the upper and lower quantiles of the distribution.

While growth opportunities show little to no difference across quantiles, firms at the upper end of the distribution, generate and hold much higher free cash flows and cash respectively, show a higher number of exercised stock options, pay more in dividends and are less levered. Firms at the $95^{\text {th }}$ quantile also exhibit the highest percentage of insider ownership concentration. The above-mentioned heterogeneity warrants the use of quantile regressions.

The quantile regression estimators are obtained by minimizing Eq. 1 below,

$$
\min _{\beta \in R^{k}}\left[\sum_{\mathrm{i} \in\left\{\mathrm{i}: y_{i} \geq x_{i}^{\prime} \beta\right\}} q\left|y_{i}-x_{i}^{\prime} \beta\right|+\sum_{\mathrm{i} \in\left\{\mathrm{i}: y_{i}<x_{i}^{\prime} \beta\right\}}(1-q)\left|y_{i}-x_{i}^{\prime} \beta\right|\right]
$$

for the $q^{\text {th }}$ quantile $(0<\mathrm{q}<1)$, where $y_{i}$ is the dependent variable, $x_{i}$ is the $\mathrm{k}$ by 1 vector of explanatory variables and $\beta$ is the coefficient vector. As suggested by Buchinsky $(1995,1998)$, we employ bootstrapping to estimate the standard errors of the coefficients. Bootstrapped standard errors are less sensitive to heteroskedasticity. Compared to OLS, the QR approach is more robust in the presence of outliers or when the distribution of the data is substantially skewed (Mata and Machado 1996). Nevertheless, we also use OLS as well as fixed effects estimation for comparison purposes. All regressions include year and industry dummy variables. 
The share repurchases determinants included in our regression model are drawn from extant theoretical and empirical literature ${ }^{4,5}$. To this respect, we control for free cash flows (FCF), cash holdings (CASH) and dividends (DIV) as extant empirical evidence generally support the free cash flow theory by Jensen (1986) which suggests that share repurchases are an alternative to dividends mechanism for distributing excess cash flows to shareholders.

The leverage (LEV) variable is included as firms which are below their target capital ratio may use share repurchases in order to adjust their capital structure (Dittmar, 2000).

Furthermore, according to the signaling-undervaluation motive, an undervalued company will most likely exhibit a history of low returns (Dittmar, 2000). Thus, we control for stock return (RETURN).

We use stock options (OPTIONS) as an additional control variable since Kahle (2002) argues that share repurchases provide the firm with shares to fund employee stock option plans and help managers offset the relevant earnings per share dilution.

Firm risk (RISK) and growth opportunities (GROWTH) are controlled for as riskier and/or growing firms are expected to retain earnings instead of distributing them either in the form of share repurchases or dividends, in order to avoid the costs of external financing (Rozeff 1982).

Finally, ownership concentration (OWNCON) is controlled for as it is theoretically associated to agency costs (Jensen and Meckling 1976).

Table 2. Variable definitions.

\begin{tabular}{|c|c|c|}
\hline Variable & Acronym & Definition - Datastream Worldscope item codes in parentheses \\
\hline $\begin{array}{l}\text { Dependent } \\
\text { Variable } \\
\text { Share } \\
\text { repurchases }{ }^{3}\end{array}$ & REP & $\begin{array}{l}\text { Purchases of common and preferred stock }(W C 04751)^{6} \text { to book } \\
\text { value of total assets }(W C 02999)\end{array}$ \\
\hline \multicolumn{3}{|l|}{$\begin{array}{l}\text { Independent } \\
\text { variables }\end{array}$} \\
\hline $\begin{array}{l}\text { Free cash } \\
\text { flows }\end{array}$ & FCF & $\begin{array}{l}\text { Cash flows from operations (WC04201) to book value of total assets } \\
(\text { WC02999) }\end{array}$ \\
\hline Cash holdings & $\mathrm{CASH}$ & $\begin{array}{l}\text { Cash and cash equivalents (WC02001) to book value of total assets } \\
(W C 02999)\end{array}$ \\
\hline Dividends & DIV & $\begin{array}{l}\text { Common cash dividends (WC04551) to book value of total assets } \\
(\text { WC02999) }\end{array}$ \\
\hline Leverage & LEV & Long term debt (WC03251) to book value of total assets (WC02999) \\
\hline $\begin{array}{l}\text { Growth } \\
\text { opportunities }\end{array}$ & GROWTH & $\begin{array}{l}\text { Capital expenditure (WC04601) to book value of total assets } \\
(W C 02999)\end{array}$ \\
\hline Stock return & RETURN & Stock's total return index from Datastream $(R I)$ \\
\hline Stock options & OPTIONS & Proceeds from stock options to book value of total assets (WC04301) \\
\hline Firm Risk & RISK & Firm's beta coefficient (WC0982) \\
\hline $\begin{array}{l}\text { Ownership } \\
\text { concentration }\end{array}$ & OWNCON & Closely-held shares (\%). (WC08021) \\
\hline
\end{tabular}

\footnotetext{
${ }^{4}$ Rozeff (1982); Jensen (1986); Dittmar (2000); Bens et al. (2003); Oswald and Young (2008); Lee and Suh (2011); Almeida et al. (2016)

${ }^{5}$ Firm size is often used as an alternative and/or second proxy for undervaluation or for external financing costs and the ability to generate free cash flows. However, these are controlled for in our model by free cash flows (FCF) and firm risk (RISK). Considering the above and for reasons of parsimony we chose not to include size as a determinant. In support of our decision, size was found to be generally insignificant in preliminary estimations with no actual effect on the other regressors.

${ }^{6}$ To measure share repurchases we use the cash flow statement item from Datastream "Purchases of common and preferred stock" as this is deemed to be the most accurate share repurchase measurement (Banyi et al.. 2008).
} 
Table 3. Descriptive statistics.

\begin{tabular}{lcrrr}
\hline \hline Variable & mean & standard deviation & minimum & maximum \\
\hline REP & 0,041 & 0,056 & 0,000 & 0,579 \\
$F C F$ & 0,115 & 0,071 & 0,000 & 0,779 \\
CASH & 0,104 & 0,115 & 0,000 & 0,844 \\
OPTIONS & 0,004 & 0,009 & 0,000 & 0,159 \\
RETURN & 0,157 & 0,362 & $-0,862$ & 7,655 \\
DIV & 0,020 & 0,025 & 0,000 & 0,379 \\
GROWTH & 0,046 & 0,045 & 0,000 & 0,490 \\
LEV & 0,204 & 0,143 & 0,000 & 0,946 \\
OWNCON & 0,123 & 0,174 & 0,000 & 1,000 \\
RISK & 1,058 & 0,540 & $-0,604$ & 4,614 \\
No. of observations & 4,281 & & & \\
\hline \hline
\end{tabular}

Note. Variable definitions are provided in Table 2.

Variable definitions and variable descriptive statistics are provided in Table 2 and Table 3 respectively ${ }^{7}$.

\section{Results}

Table 4 reports the results of the quantile,OLS, and fixed effects (at the firm level)regressions.

The F-test suggests that the effect of the majority of the explanatory variables on share repurchases is statistically different across quantiles, with the exemption of the stock return, firm risk, and cash dividends variables. Moreover, Table 3 shows that across quantiles, the coefficients of each explanatory variable exhibit changes in size, statistical significance and even sign reversals. To visually illustrate these differences in Fig. 2a-i we plot the estimated coefficients against the aforementioned quantiles along with their 95\% confidence intervals. The following analysis discusses our findings by looking at Table 3 and Fig $2 \mathrm{a}-\mathrm{i}$ in parallel.

Consistent with previous studies, OLS and fixed effects (at the firm level) estimations suggest that free cash flows, cash holdings, and stock options lead to higher repurchase activity, while growth opportunities and firm risk lead to lower share repurchase levels. Dividends, leverage, stock return, and ownership concentration do not have a statistically significant effect on share repurchases. However, the OLS estimation does not provide information on whether the effect of the aforementioned factors differs among firms with different levels of repurchase activity.

QR estimation shows that the free cash flows (FCF) and cash holdings (CASH) variables exhibit a consistently positive and statistically significant impact on share repurchases throughout the distribution. However, for both variables, the size of the coefficient increases as we move from lower to upper quantiles. This suggests, that firms with higher share repurchases levels are influenced more by excess capital when compared to firms at the lower end of the distribution. One possible reason may be higher agency costs, resulting from comparatively much higher level of excess capital in the presence of roughly equal growth opportunities. (table 1). Higher agency costs in the upper quantiles of the distribution, may explain the variation in significance and sign of the leverage variable's coefficient. Generally, the impact of leverage switches from negative to positive between firms in the lower quantiles and upper quantiles of the distribution. In lower quantiles, leverage and share repurchases are seen as alternative mechanisms of reducing agency costs of free cash flows. However, as agency costs are expected

\footnotetext{
${ }^{7}$ As a robustness check, we also run our regressions using share repurchases scaled by earnings as a dependent variable and with alternative proxies for growth opportunities (i.e market to book ratio) and firm risk (i.e. standard deviation of earnings) and obtained comparable results. These results are available from the authors upon request.
} 
to be more severe in upper quantiles, the increase of leverage ratios to reduce agency costs is positively related to share repurchases, which not only aids the reduction of free cash flow and but also ensures that the increase in debt does not lead to an increase in the firms' total capital.

Moreover, QR estimation results also support the EPS dilution hypothesis as the stock options variable has a positive and statistically significant impact on share repurchases at all quantiles. However, this impact is increasing in accordance with the firm's share repurchases activity. Again, it may be the case that as firms in the upper quantiles realize a much higher number of exercised stock options, they place greater emphasis on countering EPS dilution.

Figure $2(a-f)$. Estimated OLS and quantile regression coefficients. The black line and red lines represent the quantile regression and the OLS coefficients respectively. The black dashed lines and the red dashed lines represent the quantile regressions and the OLS regression 95\% confidence intervals respectively.
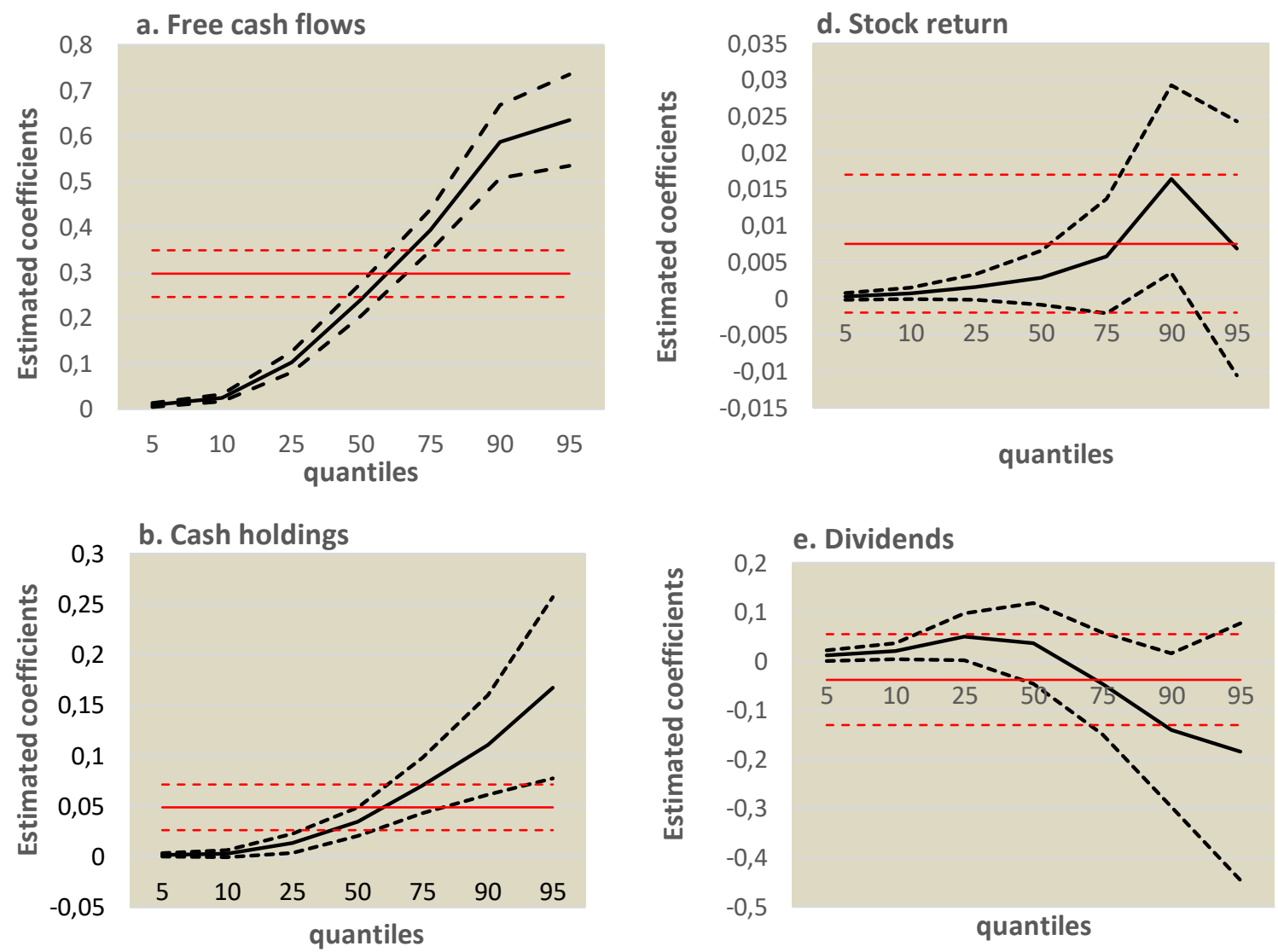

e. Dividends
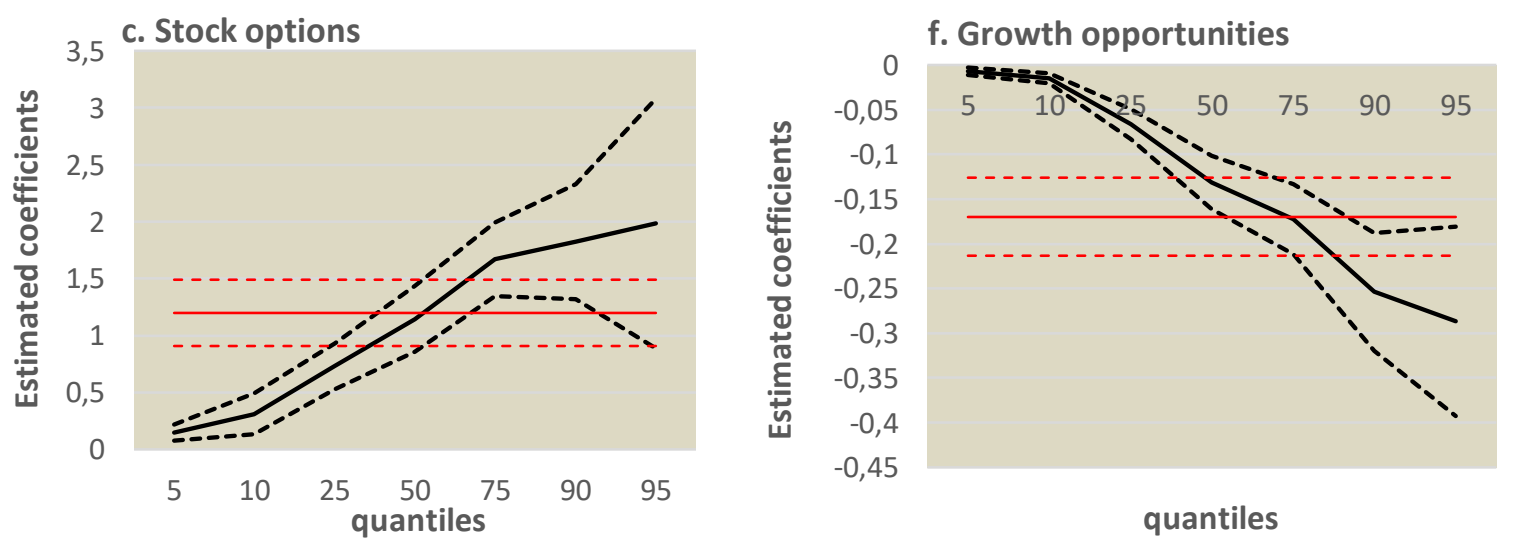
Table 4. Pooled OLS, Fixed-effects (firm level) and Quantile regression results: Dependent variable share repurchases to total assets.

\begin{tabular}{|c|c|c|c|c|c|c|c|c|c|c|}
\hline & $\begin{array}{r}(1) \\
\text { OLS }\end{array}$ & $\begin{array}{r}(2) \\
\text { Fixed Effects }\end{array}$ & $5^{\text {th }}$ Quant. & $10^{\text {th }}$ Quant. & $25^{\text {th }}$ Quant. & $\begin{array}{r}(6) \\
50^{\text {th }} \\
\text { Quant. } \\
\end{array}$ & 75 ${ }^{\text {th }}$ Quant. & $\begin{array}{r}(8) \\
90^{\text {th }} \\
\text { Quant. } \\
\end{array}$ & $\begin{array}{r}(9) \\
95^{\text {th }} \\
\text { Quant. } \\
\end{array}$ & $\begin{array}{r}(10) \\
\text { Equality } \\
\text { test } \\
\end{array}$ \\
\hline FCF & $\begin{array}{r}0,297 * * * \\
(0,026)\end{array}$ & $\begin{array}{r}0,217 * * * \\
(0,030)\end{array}$ & $\begin{array}{r}0,009 * * * \\
(0,002)\end{array}$ & $\begin{array}{r}0,024 * * * \\
(0,004)\end{array}$ & $\begin{array}{r}0,103 * * * \\
(0,011)\end{array}$ & $\begin{array}{r}0,240 * * * \\
(0,018)\end{array}$ & $\begin{array}{r}0,393 * * * \\
(0,023)\end{array}$ & $\begin{array}{r}0,587 * * * \\
(0,041)\end{array}$ & $\begin{array}{r}0,635 * * * \\
(0,051)\end{array}$ & $\begin{array}{r}56,67 \\
(0,000)\end{array}$ \\
\hline CASH & $\begin{array}{r}0,049 * * * \\
(0,012)\end{array}$ & $\begin{array}{r}0,060 * * * \\
(0,016)\end{array}$ & $\begin{array}{l}0,002 * \\
(0,001)\end{array}$ & $\begin{array}{l}0,003 * \\
(0,002)\end{array}$ & $\begin{array}{r}0,013 * * * \\
(0,005)\end{array}$ & $\begin{array}{r}0,035^{* * * *} \\
(0,007)\end{array}$ & $\begin{array}{r}0,070 * * * \\
(0,014)\end{array}$ & $\begin{array}{r}0,111 * * * \\
(0,025)\end{array}$ & $\begin{array}{r}0,167 * * * \\
(0,046)\end{array}$ & $\begin{array}{r}5,580 \\
(0,000)\end{array}$ \\
\hline OPTIONS & $\begin{array}{r}1,199 * * * \\
(0,149)\end{array}$ & $\begin{array}{r}0,858 * * * \\
(0,) 166\end{array}$ & $\begin{array}{r}0,147 * * * \\
(0,036)\end{array}$ & $\begin{array}{r}0,312 * * * \\
(0,091)\end{array}$ & $\begin{array}{r}0,731 * * * \\
(0,101)\end{array}$ & $\begin{array}{r}1,146 * * * \\
(0,147)\end{array}$ & $\begin{array}{r}1,667 * * * \\
(0,000)\end{array}$ & $\begin{array}{r}1,823 * * * \\
(0,259)\end{array}$ & $\begin{array}{r}1,984 * * * \\
(0,558)\end{array}$ & $\begin{array}{r}17,37 \\
(0,000)\end{array}$ \\
\hline RETURN & $\begin{array}{r}0,008 \\
(0,005)\end{array}$ & $\begin{array}{r}0,008 * * \\
(0,004)\end{array}$ & $\begin{array}{r}0,000 \\
(0,000)\end{array}$ & $\begin{array}{l}0,001 * \\
(0,000)\end{array}$ & $\begin{array}{l}0,002 * \\
(0,001)\end{array}$ & $\begin{array}{r}0,003 \\
(0,002)\end{array}$ & $\begin{array}{r}0,006 \\
(0,004)\end{array}$ & $\begin{array}{r}0,016^{* *} \\
(0,007)\end{array}$ & $\begin{array}{r}0,007 \\
(0,009)\end{array}$ & $\begin{array}{r}1,520 \\
(0,166)\end{array}$ \\
\hline DIV & $\begin{array}{r}-0,038 \\
(0,047)\end{array}$ & $\begin{array}{r}-0,093 * * \\
(0,053)\end{array}$ & $\begin{array}{r}0,011 * * \\
(0,006)\end{array}$ & $\begin{array}{r}0,020 * * \\
(0,008)\end{array}$ & $\begin{array}{r}0,050 * * \\
(0,024)\end{array}$ & $\begin{array}{r}0,037 \\
(0,042)\end{array}$ & $\begin{array}{r}-0,046 \\
(0,053)\end{array}$ & $\begin{array}{r}-0,140 * \\
(0,080)\end{array}$ & $\begin{array}{r}-0,184 \\
(0,134)\end{array}$ & $\begin{array}{r}1,630 \\
(0,134)\end{array}$ \\
\hline GROWTH & $\begin{array}{r}-0,170 * * * \\
(0,022)\end{array}$ & $\begin{array}{r}-0,134 * * * \\
(0,027)\end{array}$ & $\begin{array}{r}-0,007 * * * \\
(0,002)\end{array}$ & $\begin{array}{r}-0,015 * * * \\
(0,003)\end{array}$ & $\begin{array}{r}-0,066 * * * \\
(0,008)\end{array}$ & $\begin{array}{r}-0,131 * * * \\
(0,015)\end{array}$ & $\begin{array}{r}-0,172 * * * \\
(0,020)\end{array}$ & $\begin{array}{r}-0,254 * * * \\
(0,034)\end{array}$ & $\begin{array}{r}-0,287 * * * \\
(0,054)\end{array}$ & $\begin{array}{r}16,95 \\
(0,000)\end{array}$ \\
\hline LEV & $\begin{array}{r}0,008 \\
(0,007) \\
-0,002\end{array}$ & $\begin{array}{r}0,015^{*} \\
(0,009) \\
-0,002\end{array}$ & $\begin{array}{r}0,000 \\
(0,000) \\
-0,001\end{array}$ & $\begin{array}{r}-0,002 * * \\
(0,001) \\
-0,002 * *\end{array}$ & $\begin{array}{r}-0,004 * * \\
(0,002) \\
-0,009 * * *\end{array}$ & $\begin{array}{r}-0,002 \\
(0,003) \\
-0,014 * * *\end{array}$ & $\begin{array}{r}0,001 \\
(0,005) \\
-0,005\end{array}$ & $\begin{array}{r}0,018 \\
(0,013) \\
0,019\end{array}$ & $\begin{array}{r}0,063 * * * \\
(0,024) \\
0,087 * * *\end{array}$ & $\begin{array}{r}2,490 \\
(0,021) \\
7,600\end{array}$ \\
\hline OWN_CON & $(0,006)$ & $(0,008)$ & $(0,001)$ & $(0,001)$ & $(0,002)$ & $(0,03)$ & $(0,005)$ & $(0,014)$ & $(0,032)$ & $(0,000)$ \\
\hline RISK & $\begin{array}{r}-0,003 * * \\
(0,001)\end{array}$ & $\begin{array}{l}-0,003 * \\
(0,002)\end{array}$ & $\begin{array}{r}0,000 \\
(0,000)\end{array}$ & $\begin{array}{r}0,000 \\
(0,000)\end{array}$ & $\begin{array}{r}-0,001 \\
(0,001)\end{array}$ & $\begin{array}{r}-0,002 \\
(0,001)\end{array}$ & $\begin{array}{r}-0,003 * * \\
(0,002)\end{array}$ & $\begin{array}{r}-0,001 \\
(0,003)\end{array}$ & $\begin{array}{r}0,001 \\
(0,005)\end{array}$ & $\begin{array}{r}1,250 \\
(0,276)\end{array}$ \\
\hline $\mathrm{R}^{2}$ & 0,278 & 0,270 & 0,011 & 0,027 & 0,091 & 0,174 & 0,235 & 0,275 & 0,293 & \\
\hline
\end{tabular}

\section{Notes:}

- Columns (3) - (9) report the quantile regression results at the 5th, 10th,25th,50th, 75th, 90th, 95th quantile, respectively. Bootstrapped standard errors, obtained by 1000 replications are in parentheses, besides OLS and fixed-effects (firm level) were figures in parentheses are robust standard errors. Column (1) reports the OLS regression results with and without fixed effects (at the firm level) for comparison. Column (10) reports the F-statistic of our mean equality test which has a null hypothesis that the estimated coefficients of each explanatory variable are equal across all quantiles. P- values are reported in parentheses. Variable definitions are provided in table 2. OLS and QR estimations include year and industry dummies. Fixed-effect (firm level) estimations include year dummies.

- * indicates statistical significance at the $10 \%$ level

- ** indicates statistical significance at the $5 \%$ level

- *** indicates statistical significance at the $1 \%$ level 
Figure $2(g-i)$. Estimated OLS and quantile regression coefficients. The black line and red lines represent the quantile regression and the OLS coefficients respectively. The black dashed lines and the red dashed lines represent the quantile regressions and the OLS regression 95\% confidence intervals respectively.
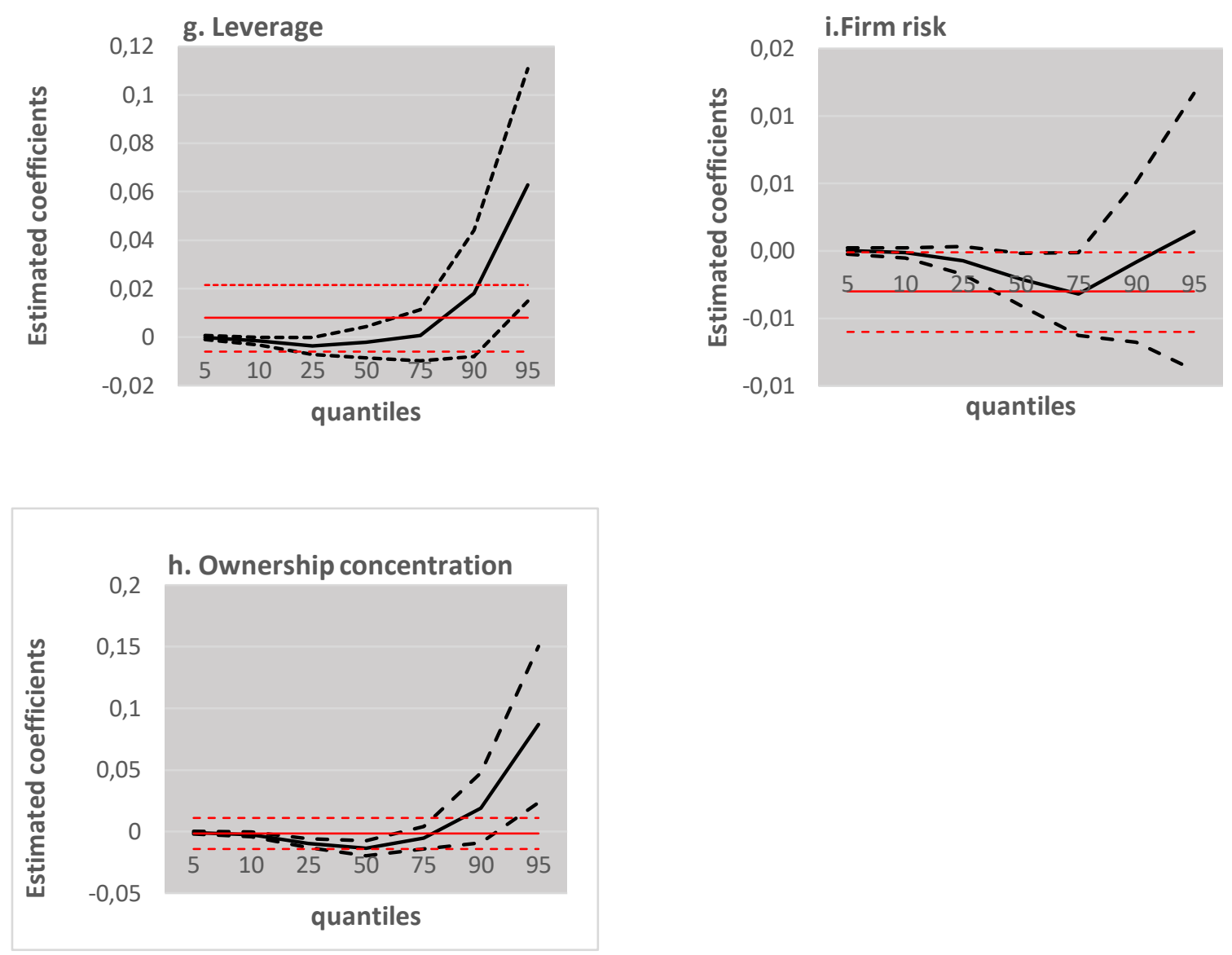

Growth opportunities have a negative and statistically significant effect on share repurchases, across all quantiles. This negative effect is more pronounced as we move to the upper quantiles. A higher repurchase activity corresponds to higher outflows. Therefore, to avoid the costs of external financing (i.e. Rozeff 1982) firms in upper quantiles may comparatively reduce share repurchases in the presence of growth opportunities.

For the ownership concentration variable, we document a sign reversal between quantiles. The respective coefficient's sign is negative at, at the lower and middle parts (10th,25th,50th quantiles), to positive at the higher end ( $95^{\text {th }}$ quantile) of the share repurchases distribution. A possible reason may be the comparatively higher level of ownership concentration at the $95^{\text {th }}$ quantile (Table 1). This may indicate managerial entrenchment agency related costs and thus a need for higher share repurchases as a mechanism to reduce these costs.

Regarding the stock return and firm risk variable, we cannot reach any conclusions regarding the respective coefficients since confidence intervals for these variables are generally quite wide. Share repurchases and dividends appear to complementary distribution mechanisms at the lower quantiles (5th,10th,25th) as the respective coefficient is positive. The coefficient loses significance at the 50th quantile and turns negative at the upper quantiles. For these firms share repurchases represent a significant outflow of funds. Considering, the stickiness of dividends such firms may ensure the future sustainability of dividend increases through reductions of funds towards share repurchases. 


\section{Concluding remarks}

Earlier research utilizes conventional conditional mean estimators which evaluate the mean effect of various determinants on share repurchase levels. Results reported by such estimations are often in conflict in terms of the effect's size, significance and sometimes even direction. However, as we show in this study, firm repurchase behaviour and firm characteristics at different points of the share repurchases distribution exhibit a high degree of heterogeneity. Our findings confirm that in cases like this, conventional estimation techniques entail a loss of information. Specifically, the aforementioned heterogeneity leads to an asymmetric impact of relevant determinants between firms with different repurchase activity. Our results show a substantial difference between coefficients provided by OLS estimations and coefficients at different quantiles from our QR estimations. These differences include changes in sign (as in leverage, ownership concentration, dividends), size (as in free cash flows, cash holdings, stock options), and significance of the coefficient (as in stock returns, firm risk). Therefore, to a certain degree, discrepancies regarding results of earlier studies using conditional mean estimations, can be explained by the fact that the impact of widely adopted determinants of share repurchases is not the same across a given distribution of repurchasing firms. To this respect, this study offers a more complete understanding of the determinants of share repurchases and is likely to explain conflicting findings in the prior literature. Furthermore, it supports that share repurchases determinants should not be evaluated for highly heterogeneous groups of firms in terms of share repurchase activity using conventional conditional mean estimators.

\section{References}

Almeida, H., Fos, V., and Kronlund, M. (2016) The real effects of share repurchases, Journal of Financial Economics, 119(1), 168-185.

Banyi, M. L., Dyl, E. A., and Kahle, K. M. (2008) Errors in estimating share repurchases, Journal of Corporate Finance, 14(4), 460-474.

Benhamouda, Z., and Watson R. (2010) A research note on the determinants of UK corporate share repurchase decisions, Applied Financial Economics, 20(7), 529-541.

Bens, D., Nagar, V., Skinner, D., and Wong, F. (2003) Employee stock options, EPS dilution, and stock repurchases, Journal of Accounting \& Economics, 36(1-3), 51-90.

Brav, A., Graham, J. R., Harvey, C. R., and Michaely, R. (2005) Payout policy in the 21st century, Journal of Financial Economics, 77(3), 483-527.

Buchinsky, M. (1995) Estimating the asymptotic covariance matrix for quantile regression models, a Monte Carlo study, Journal of Econometrics, 68(2), 303-338.

Buchinsky, M. (1998) Recent Advances in Quantile Regression Models: A Practical Guideline for Empirical Research, The Journal of Human Resources, 33(1) 88-126.

Dittmar, A. K. (2000) Why do firms repurchase stock?, Journal of Business, 73(3), 331-355.

Fattouh, B., Harris, L., and Scaramozzino, P. (2008) Non-linearity in the determinants of capital structure: evidence from UK firms, Empirical Economics, 34, 417-438

Fattouh, B., Scaramozzino, P., and Harris, L. (2005) Capital structure in South Korea: a quantile regression approach, Journal of Development Economics, 76(1), 231-250.

Fenn, G., and Liang, N. (2001) Corporate payout policy and managerial stock incentives, Journal of Financial Economics, 60(1), 45-72.

Jensen, M. (1986) Agency Costs of Free Cash Flow, Corporate Finance, and Takeovers, The American Economic Review, 76(2), 323-329.

Jensen, M. C., and Meckling, W. H. (1976) Theory of the firm: Managerial behavior, agency costs and ownership structure, Journal of Financial Economics, 3(4), 305-360. 
Kahle, K. (2002) When a buyback isn't a buyback: Open market repurchases and employee options, Journal of Financial Economics, 63(2), 1-41.

Koenker, R., and Bassett, Jr., G. (1978) Regression quantiles, Econometrica, 46(1), 33-50.

Lee, B. S., and Suh, J. (2011) Cash holdings and share repurchases: International evidence, Journal of Corporate Finance, 17(5), 1306-1329.

Mata, J. and Machado, J. A. F. (1996) Firm start-up size: a conditional quantile approach, European Economic Review, 40(6), 1305-1323.

Oswald, S. and Young, D., (2008) Share reacquisitions, surplus cash, and agency problems, Journal of Banking \& Finance, 32(5), 795-806.

Rozeff, M. (1982) Growth, beta and agency costs as determinants of dividend payout ratios, The Journal of Financial Research, 5(3), 249-259.

Sánchez-Vidal, F. J. (2014) High debt companies' leverage determinants in Spain: A quantile regression approach, Economic Modelling, 36, 455-465. 